\title{
Ecosystem Services are Social-ecological Services in a Traditional Pastoral System: the Case of California's Mediterranean Rangelands
}

\author{
$\underline{\text { Lynn Huntsinger }}^{1}$ and $\underline{\text { José L. Oviedo }}^{2}$
}

\begin{abstract}
When attempting to value ecosystem services and support their production, two critical aspects may be neglected. The term "ecosystem services" implies that they are a function of natural processes; yet, human interaction with the environment may be key to the production of many. This can contribute to a misconception that ecosystem service production depends on, or is enhanced by, the coercion or removal of human industry. Second, in programs designed to encourage ecosystem service production and maintenance, too often the inter-relationship of such services with social and ecological processes and drivers at multiple scales is ignored. Thinking of such services as "social-ecological services" can reinforce the importance of human culture, perspectives, and economies to the production of ecosystem services. Using a social-ecological systems perspective, we explore the integral role of human activity and decisions at pasture, ranch, and landscape scales. Just as it does for understanding ecosystems, a hierarchical, multiscaled framework facilitates exploring the complexity of social-ecological systems as producers of ecosystem services, to develop approaches for the conservation of such services. Using California's Mediterranean rangelands as a study area, we suggest that using a multiscaled approach that considers the importance of the differing drivers and processes at each scale and the interactions among scales, and that incorporates social-ecological systems concepts, may help avoid mistakes caused by narrow assumptions about "natural" systems, and a lack of understanding of the need for integrated, multiscaled conservation programs.
\end{abstract}

Key Words: endangered species, landscape, pasture, ranching, scale, social-ecological system, vernal pools

\section{INTRODUCTION}

The term "ecosystem services" was coined to express the value of natural systems to human well-being. Yet ecosystem processes are seldom solely natural, but instead are part of social-ecological systems where human interaction with the environment shapes both ecosystems and culture. Examination of the production of ecosystem services from a social-ecological systems perspective may help avoid mistakes caused by narrow assumptions about "natural" systems. The processes, interactions, and drivers of social-ecological systems occur at multiple scales; differing processes and drivers are important at different scales (Holling 2001). Too often, the need to consider scale, and the feedbacks among scales, in understanding social-ecological systems is neglected. California's Mediterranean rangelands, or the woodlands, grasslands, and shrublands of the Mediterranean climate zone (Fig. 1), offer an example of the importance of attention to the interaction of social and ecological processes at different scales in the production of ecosystem services. There is a need for integrated, multiscaled conservation programs to protect and enhance the flow of what might better be termed "social-ecological services" from social-ecological systems.

Extensive pastoralism, a form of traditional agriculture, has been termed a social-ecological system (McAllister et al. 2006), a perpetually dynamic, complex system with continuous adaptation to the unpredictable rangeland environment and human management (Gunderson and Holling 2002). We focus on the social-ecological system of ranching in California's Mediterranean rangelands because it combines the production of commodities and a diverse array of ecosystem services. As a result, rangelands used for ranching are often referred to as "working landscapes" (Huntsinger and Sayre 2007). As they are a form of agriculture, they can also be referred to as "agro-ecosystems," although this term implies more direct manipulation of ecosystems through crop production than is characteristic of pastoral systems (Sayre et al. 2012). Working landscapes and agro-ecosystems are socialecological systems, and they produce ecosystem services that are the product of human industry and ecosystem processes. Many such services could be termed social-ecological services, to distinguish them from ecosystem services produced mostly by ecological processes alone, whether they are provisioning, cultural, regulatory, or supporting services. For example, the term "cultural ecosystem service" implies that something coming from an ecosystem has cultural value, rather than indicating that cultural activities cogenerated the service, as in a social-ecological service or, if necessary, a "cultural social-ecological service." Understanding that culture cogenerates ecosystem services lends richness to the idea of cultural landscapes, the topic of this special issue. This understanding would encourage conservation efforts that recognize the need to maintain the human activity to sustain the services. Here, examples of how human activities on rangelands generate social-ecological services are identified and discussed at pasture, ranch, and landscape scales. We explore examples of programs and practices that support ecosystem services that are, in fact, social-ecological services.

\section{Social-ecological services?}

A straightforward definition of ecosystem services is "the benefits people obtain from ecosystems" (Millennium Ecosystem Assessment 2003:49). The concept is widely used to promote conservation programs, but has been criticized as obscuring the complexity of natural systems (Norgaard 2010). One aspect of this obscured complexity is that, to varying degrees, ecosystems have been modified and even created by human activity, sometimes in ways that alter the flow and characteristics of the benefits that accrue to people. As a result, human activity is too often assumed to be necessarily harmful to ecosystem service production, and long-term human activity may be discounted in defining the "historical range of variability" of ecosystems (Seastedt et al. 2008). Problems arise from disregarding the human

${ }^{1}$ Department of Environmental Science, Policy, and Management, University of California, Berkeley, ${ }^{2}$ Institute of Public Goods and Policies (IPP), Consejo Superior de Investigaciones Científicas (CSIC), Madrid 
role as a cogenerating factor. When it comes to settings such as the natural-looking rangelands characteristic of extensive pastoral systems, one manifestation in the field of ecology is a disregard for how ecosystems have been shaped by human activity, which can lead to misunderstandings and failure to predict responses to current management (Foster et al. 2003, Seastedt et al. 2008). Acknowledging that some ecosystem services are socialecological services might make it more obvious that the role of the human past and present cannot be ignored in the study of the structure and function of contemporary ecosystems. For example, although it was long disregarded, indigenous knowledge and management history is now believed to be crucial to understanding California ecosystems (Anderson 2005).

Related to this distinction, a problem for conservationists and policy makers is the increasing recognition that sometimes ecosystems, once set aside and restricted from human use, change in ways that alter the flow of ecosystem services. Or, they change from producing the social-ecological services that the conservation effort was designed to preserve, to producing fewer or different ecosystem services. For many traditional agricultural landscapes, either abandonment or intensification can lead to a reduction in biodiversity, aesthetics, and other ecosystem services (Birks et al. 1988, Bugalho et al. 2011, Schleyer and Plieninger 2011). In California, evidence is accumulating that the ecosystem services that support some species of plants and animals are at least in part dependent on the presence of livestock production (Huntsinger et al. 2012).

California's Mediterranean rangelands have undergone a severe reduction in native burning in the last 200 years (Blackburn and Anderson 1993, Anderson 2005), and the livestock grazing that has been the dominant use over the same period is in decline, giving ground to development, intensive agriculture, and alternative uses (California Department of Forestry and Fire Protection-Fire and Resource Assessment 2010). It is understood that both cause ecological change. Yet, "cessation" of human activity or forms of management is seldom, if ever, considered worthy of environmental review in the United States (Huntsinger et al. 2012). Would increased recognition that many of the "services" provided to society by the Mediterranean rangelands in California are maintained by human activities cause us to rethink this? Within the social-ecological systems (SES) framework, human activity is integral and can be environmentally positive, but the problem with the concept of ecosystem services is its implication that service production is solely a function of the natural ecosystem.

Therefore, the production and flow of social-ecological services derives from the interaction of humans and the environment. Maintaining or enhancing these services relies on supporting human practices and cultures that create desirable ecosystem services and ecosystem processes, a challenge to conservationists worldwide. Attention to scale in framing and analyzing problems and solutions is argued to be important to both ecological and social analysis (Fox 1992, Holling 2001, McAllister et al. 2006, Plieninger et al. 2012b). At any particular scale, higher levels set the conditions within which the lower levels function, whereas the lower levels determine what is possible at larger scales (Allen and Starr 1982). Panarchy theory envisions each scale as a complex, adaptive system (Holling 2001, Gunderson and Holling 2002).
Although different processes may dominate at different scales, they interact: actions taken at one scale will influence the others, and feedbacks among system components and scales are characteristic (Allen and Starr 1982, Holling 2001). Here, we use scale to examine the social-ecological processes and interactions that support the production of ecosystem services on California's Mediterranean rangelands, with due attention to the role of human practice and processes at each scale. The quality and abundance of many of the ecosystem services that such "working landscapes" provide are a result of the interaction of ranching and the environment.

\section{STUDY AREA}

The Mediterranean rangelands of California are comprised mostly of oak woodlands (2 million ha), annual grasslands (10 million ha), and shrublands or chaparral (3 million ha) ranging from sea level to about 2000-m elevation (Fig. 1; California Department of Forestry and Fire Protection-Fire and Resource Assessment Program 2003). Although crop production has filled most of the lower elevation lands, the foothills along the coast and Sierra are largely the domain of the ranching industry, with montane ranges sometimes used for transhumance (Huntsinger et al. 2010a). In the woodlands, canopy cover varies from complete closure in canyon thickets to open savanna woodlands on foothill slopes (Allen-Diaz et al. 1999, 2007; Fig. 2). Overstory oaks include seven common species, but the most common are blue oak (Quercus kellogii) and California live oak (Quercus agrifolia). Shrublands include manzanita (Arctostaphylos spp.), chamise (Adenostema fasciculatum), sages (Salvia spp.), and scrub oaks (Quercus dumosa and berberidifolia) as common dominants. Today, grassland species are largely arrivals from the Mediterranean regions of Europe, commonly including varieties of wild oats (Avena spp.) and brome grass (Bromus spp.). The replacement of the native grassland, brought about by the introduction of aggressive nonnatives, cultivation, and livestock production during colonization, has created a grassland that is different in structure and temporality than the original grasslands, with as yet not fully understood consequences for native flora and fauna. In many places, perennial bunchgrasses have been replaced or reduced. In drier areas, there may have originally been a higher proportion of broadleaved species and native annuals before contact (Holstein 2011). These "novel" rangelands have been recognized worldwide as significant for biodiversity conservation as part of the California floristic province biodiversity hot spot (Myers et al. 2000). More than $87 \%$ of the woodlands and grasslands are in private ownership (California Department of Forestry and Fire Protection-Fire and Resource Assessment Program 2003), around two-thirds are grazed by livestock (Huntsinger et al. 2010b), and livestock grazing has been a widespread use for around 200 years depending on the region (Burcham 1982).

\section{ANALYSIS AT THREE LEVELS: PASTURE, RANCH, AND LANDSCAPE}

For the purpose of this analysis, we consider California Mediterranean rangelands at three loosely defined scales: the landscape, ranch, and pasture. The landscape is the most extensive scale, and usually includes more than one ranch. The ranch scale 
Fig. 1. Oak woodlands, annual grasslands, and shrublands are the common rangelands within the Mediterranean climate zone of California. (Adapted from California Department of Forestry and Fire Protection-Fire and Resource Assessment Program 2006)

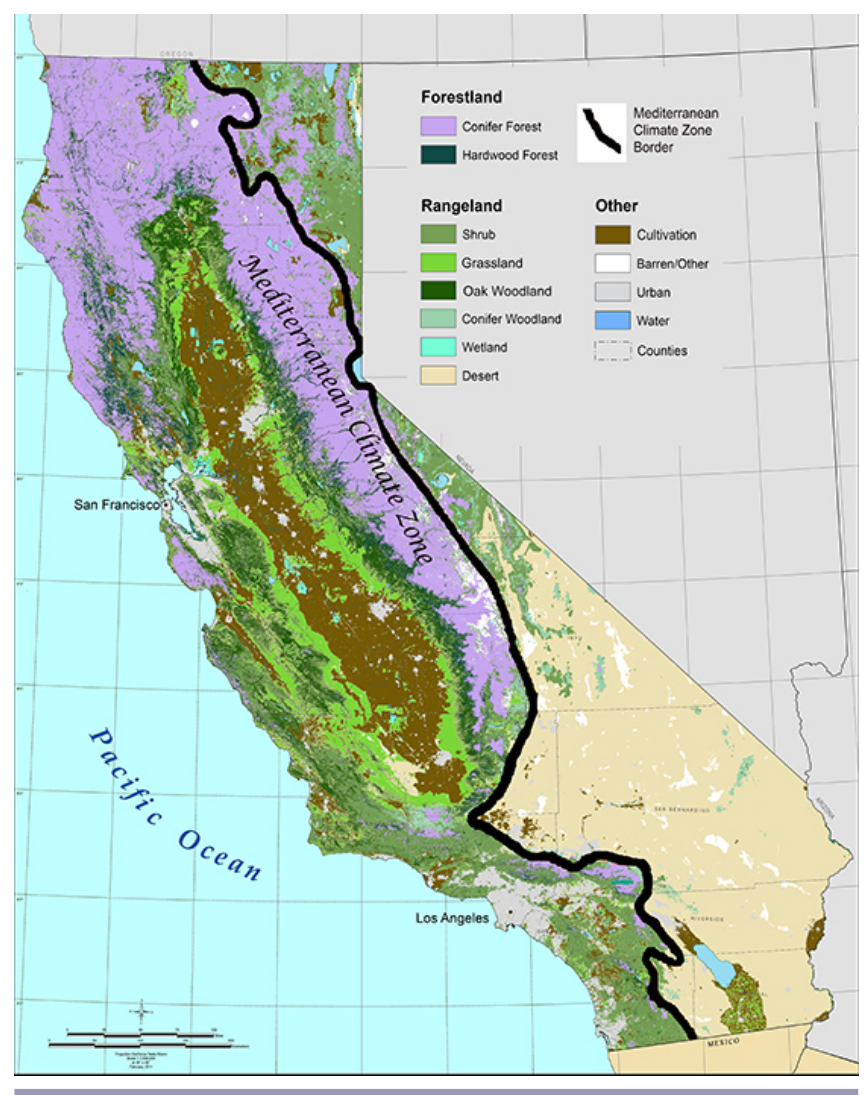

is that within the borders of a pastoral enterprise - the rangelands used by a household or company. The pasture scale is a unit of rangeland used for grazing, and a typical ranch has several pastures or grazing areas. The ecosystem services produced are different at each scale, and are generated by the differing socialecological processes. There are trade-offs and synergies among services at each level, and interdependence and feedback among levels.

\section{Ecosystem services at the pasture scale}

The process of livestock grazing is an integral part of the ranching social-ecological system. At the pasture scale, how plants and animals respond to grazing management shapes ecosystem structure and function. In California, the impacts of livestock grazing on ecosystem services such as biodiversity and oak regeneration have been frequently researched by ecological scientists, and there is also growing interest in the potential of rangeland plant communities to sequester carbon (Booker et al. 2012). A growing body of literature shows that livestock grazing can enhance biodiversity (Barry 2011, Huntsinger et al. 2007). In part, this literature came out of incidents where, as part of conservation or preservation efforts, livestock grazing was removed and, subsequently, species of interest or habitat of interest disappeared. One notable example was the disappearance of the endangered Bay checkerspot butterfly (Euphydryas editha bayensis) from the Jasper Ridge Preserve. Although scientists came up with a variety of alternative explanations for the loss of the species, including climate change and natural population dynamics (McGarrahan 1997), it took a historian to note that the decline coincided with the removal of livestock grazing (Stanford University 2013). Subsequent research supports the conclusion that by controlling invasive annual grasses, livestock grazing enhances and maintains the butterfly's habitat (Weiss 1999). In another example, managers of preserve lands in the San Francisco Bay Area decided to remove grazing to protect the environment, and found that the endangered goldfield (Lasthenia conjugens), a major target of their efforts, declined drastically. Reintroducing grazing brought the flowers back (Cuff 2011). In the Jepson Prairie Reserve of the Sacramento Valley, exclusion of sheep reduced grassland biodiversity (Reiner 1999).

Fig. 2. Annual grasslands, oak woodlands, and chaparral in the San Francisco Bay area.

Note: plant community distribution is strongly influenced by soil characteristics.

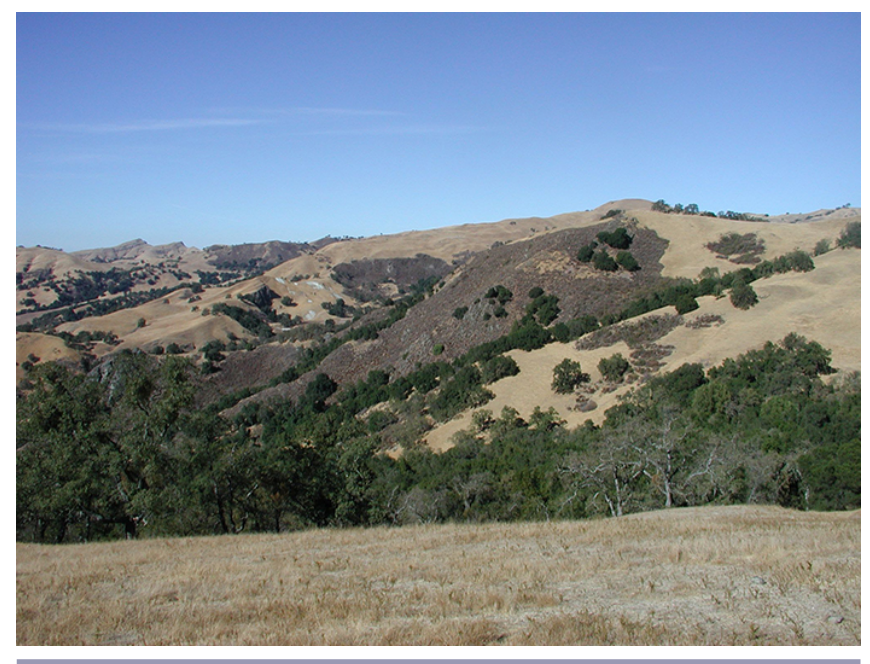

Research and management experience has revealed positive impacts from grazing on many rare species. Species may benefit from grazing that alters grassland structure to create shorter grass, more openings, or more structural heterogeneity in general than is found when livestock are excluded. These include burrowing owls (Athene cunicularia; Nuzum 2005), a variety of beetles (Dennis et al. 1997), kit fox (Vulpes macrotis mutica; United States Department of the Interior Fish and Wildlife Service 2010), kangaroo rats (Dipodomys stephensi; United States Department of the Interior Fish and Wildlife Service 1997, Kelt et al. 2005, Germano et al. 2011), blunt-nosed leopard lizards (Gambelia sila), San Joaquin antelope squirrel (Ammospermophilus nelson; Germano et al. 2011), and wildflower displays (Barry 2011).

A host of rare flora and fauna associated with vernal pools are more common in grazed rangelands (Marty 2005, Pyke and Marty 2005). Endemic-rich vernal pools form in the spring on 
shallow claypan in some parts of the California grassland. Grazing has been shown to create longer inundation periods in the pools by preventing quick growing, invasive annual grasses from using all the water (Pyke and Marty 2005). Reducing the stature of nonnative grasses also allows the low-growing endemics to thrive, maintaining species diversity (Fig. 3; Marty 2005, Pyke and Marty 2005). Grazing can be used to manage other invasive species and to reduce grassland fuel loadings. The type, timing, intensity, and duration of livestock grazing is determined by the decisions of the livestock manager, which are influenced by the manager's values, goals, knowledge, and resources, among other things. Within the constraints of the unpredictable Mediterranean climate, these factors shape plant and animal response in the pasture and, in turn, the flow of ecosystem services.

Fig. 3. Grazing increased species richness in vernal pools in California annual grasslands. Change in native species richness (s) per quadrat between 2001-2003 in four grazing treatments: continuously grazed, dry season grazed, wet season grazed, and ungrazed.

n.s. $=$ not significant,${ }^{*}=\mathrm{p}<0.05 a$ vs. $b,{ }^{* *}=\mathrm{p}<0.01 a$ vs. $b$. MANOVA (adapted from Marty 2005)

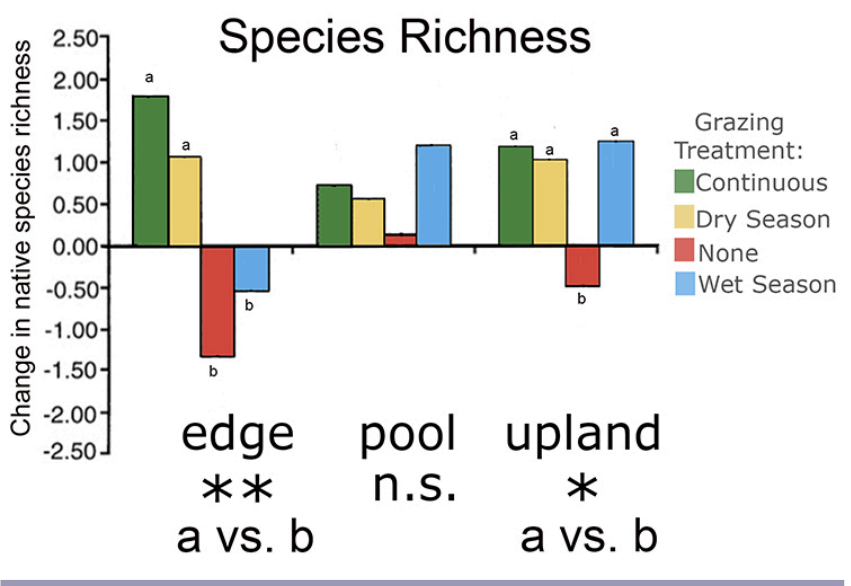

There are trade-offs between livestock grazing and some ecosystem services, but there may also be feedbacks that help buffer these trade-offs. Livestock, like herbivorous wildlife and insects, will browse oak seedlings and can prevent young oaks from growing into mature oaks in some cases (Reiner and Craig 2011), reducing the many ecosystem services provided by an oak stand. On the other hand, the presence of oaks has been shown to be neutral to beneficial for livestock production. When oaks are at a canopy cover of $50 \%$ or less, they do not reduce forage production and may lengthen the green forage season through shading and fog drip. In fact, trees may act as a nutrient pump, dropping leaves fed from deep soil layers onto the surface (Frost and McDougald 1989, Frost et al. 1991, 1997). Frost et al. (1991) found that, by early spring, forage production beneath the blue oak (Quercus douglasii) canopy was consistently greater than in open grassland, an increase that was also present at the time of peak standing crop. In addition to the increased production, the forage beneath blue oaks was generally of better quality, particularly in terms of protein content. The increased forage production and higher protein content of understory forage under scattered blue oaks feeds back into rancher decisions to retain or remove oaks. In particular, it may stimulate ranchers to manage grazing to support replacement of trees (McCreary 2001).

Research into the decision making of landowners and managers about pasture management is as important to ecosystem service production at this level, as is further ecological research about the relationships between ecosystem services and grazing. Scaleappropriate policies include cost-sharing programs such as the Environmental Quality Improvement Program (EQIP) that offer incentives for certain practices by landowners and managers, including managing ponds and water developments to conserve aquatic species, improve wildlife habitat, and protect water quality. This is a form of "payment for ecosystem services" (PES). Ranchers have considerable interest in payment for ecosystem services, although they may not recognize it by name (Cheatum et al. 2011). Interest has been expressed in carbon sequestration and habitat improvement for endangered species, among other possibilities that can complement livestock grazing. Fee hunting, in the sense that it encourages landowners to manage habitat for wildlife, is an existing market for ecosystem services. Markets, payments, and cost shares help support the enterprise financially. They interact with the next scale up, the ranch scale, and can maintain the enterprise that creates and maintains the pastures supporting the services. Payments for ecosystem services may also transmit a sense of social approval to the manager, feeding back to greater interest in ecosystem service production. Likewise, regulations protecting endangered species, water quality, air quality, and wildlife in general can have important impacts on pasture management practices. They also interact with the ranch scale, sometimes conferring costs and a sense of social disapproval that affects ranch sustainability (Liffmann et al. 2000). At a still higher level, the configuration of the landscape, the livestock market, weather, and other processes may constrain the choices of the ranch manager.

\section{The ranch scale}

At the ranch scale, management and research opportunities focus on sustaining the ranch enterprise and supporting ranch stewardship. Synergistic opportunities for ecosystem service production include diversification of income streams in environmentally positive ways, and finding ways for landowners to benefit financially from the ecosystem services provided by rangelands. Threats at this level include lack of economic sustainability, increased management costs and opportunity costs from competing uses, and the lack of an heir interested in ranching (Brunson and Huntsinger 2008). Various studies have examined the economic benefits of diversifying income streams. Standiford and Howitt (1992) found that depending on site productivity, adding sustainably harvested fuelwood and fee hunting could substantially increase income for California ranchers with oak woodlands, creating an economic imperative for maintaining oaks and their associated ecosystem services. Oviedo et al. (2013) showed that for two ranch case studies in the Sacramento Valley foothills, ranchers benefited from marketing firewood, hunting, and crops.

At the ranch scale, landowner motives and decisions have a profound effect on ranch sustainability and production of ecosystem services from ranch stewardship. In 1985, a property- 
Table 1. General characteristics of oak woodland landowners as related to property size.

\begin{tabular}{ll}
\hline \hline Owner of small property $(<100 \mathrm{ha})$ & Owner of large property $(>100$ ha $)$ \\
\hline Does not sell products from land & Sell products, most often livestock \\
More often absentee & More likely to be a resident owner \\
More recent arrival & Long-term owner \\
Relatively amenable to oak use regulation, thinks oaks are "being & Against oak use regulation, does not "think oaks are being lost \\
lost in California" & in California" \\
Less likely to thin or cut some oaks & More likely to cut or thin some oaks \\
Main source of income is other than ranching, farming, or timber & Main source of income is ranching \\
Increasing in number & Relatively stable in number \\
\hline
\end{tabular}

Notes: Sourced from Huntsinger et al. (1990, 1997, and 2010b).

Natural beauty is an important and increasing reason given for living in the oak woodlands by most landowners.

based survey of oak woodland landowners statewide was conducted to identify the goals and practices of hardwood rangeland landowners and to examine relationships between landowner characteristics, values, and management (Huntsinger and Fortmann 1990). An estimated 10\% or more of California's oak woodlands were owned by the respondents at each date. Response rates varied from $80 \%-64 \%$. The survey was repeated in 1992 (Huntsinger et al. 1997) and in 2004 (Huntsinger et al. $2010 b$ ). The objectives were to identify changes in landowner characteristics, practices, land uses, and attitudes over time to update education and research activities, and to provide information for legislators considering regulation of oak harvest. The survey provides an unusual opportunity to look at change in landowner attitudes and practices over time (Huntsinger et al. $2010 b)$.

Overall, property size was a powerful indicator of the needs and interests of landowners. In 1985, owners of properties $>1000$ ha were almost always engaged in ranching enterprises, whereas owners of properties of $<80$ ha were more amenity oriented (Table 1; Huntsinger et al. 1997). A longitudinal examination of change from 1985-2004 revealed some important trends. First, landowners changed their behavior with respect to oaks over the duration of the study, which was concurrent with a statewide oak conservation education and research program (Fig. 4). Such results lend support to the argument that education can contribute to stimulating long-term cultural change in landowner behavior and production of ecosystem services (de Snoo et al. 2012). This change in behavior was not associated with attitudes towards the government role in natural resource regulation and control, or to the strength of the amenity values a landowner had for their land. Direct subsidies for changes in practices were not offered. Instead, reduced cutting was linked to contact with an advisory service like the University of California Cooperative Extension Services or a conservation NGO, and also to having sold or donated, or being interested in selling or donating, the right to change land use out of ranching or farming to a land trust or agency (a "conservation easement"). This was termed a "permanence syndrome," where the long-term outlook of the landowner led to greater investment in the environment and consequently, ecosystem services, as opposed to the "impermanence syndrome" where the opposite occurs (Heimlich and Anderson 1987, Liffmann et al. 2000, Huntsinger et al. 2010b).
Fig. 4. Survey of California oak woodland landowners repeated three times from 1985-2004. Note: Landowners and managers reduced oak cutting and increased oak planting. Over the same time period, a statewide outreach and education program emphasized the values of retaining oaks rather than cutting them to increase forage production (Huntsinger et al. 2010b).

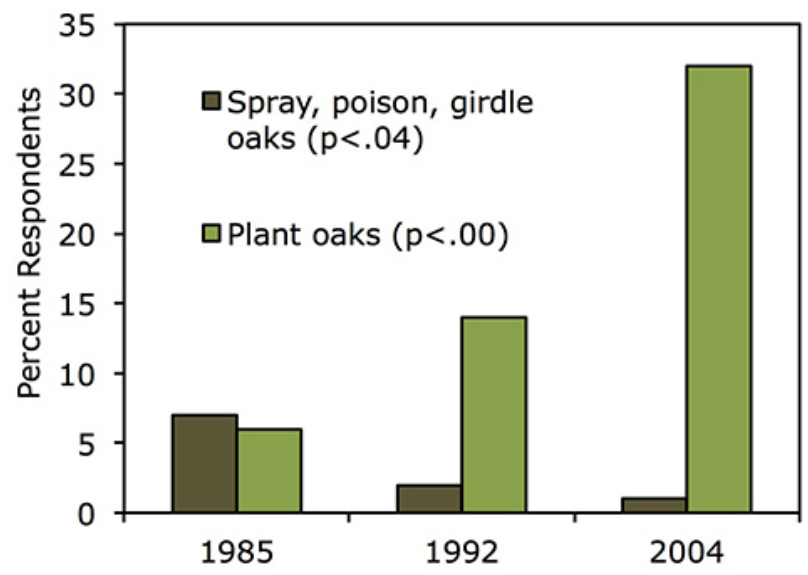

Over the research period, landowner interest in various amenities and lifestyle values increased (Fig. 5), creating opportunities for enhancing and diversifying ecosystem service flows as landowner interest in such services from their lands increases. Livestock production remains the economic backbone of oak woodland enterprises. However, the proportion of landowners reporting that consumption of diverse ecological, cultural, and lifestyle amenities from oak woodland properties was important to them increased between 1985 and 2004, especially among owners of larger properties (Fig. 6; Huntsinger et al. 2010b). The enjoyment of rangeland amenities by ranchers is an important factor in sustainability at the ranch scale.

Landowner-consumed ecosystem services at the ranch scale Many of the amenities ranchers consume from the land, such as enjoyment of the natural beauty of rangelands, recreational opportunities, or living in the country (Liffmann et al. 2000) can 
be seen as ecosystem services. The public enjoys the natural beauty of rangelands as well, and many such ecosystem services are in fact shared with the public, a synergy that can help gain public support for supporting ecosystem services from ranch lands (Huntsinger et al. 2010b). Sustaining ecosystem service production can draw on the desire of landowners to benefit from such services by living on a ranch, and this has been well demonstrated to provide a powerful motivation for ranch ownership (Torell et al. 2005). Enjoyment of natural beauty creates feedback to rancher decisions, motivating management to maintain this characteristic (McClaran and Bartolome 1985), providing an example of how "natural beauty" is, in this case, a social-ecological service.

Fig. 5. Landowner reasons for living in the oak woodlands. Note: Landowner interest in amenities and lifestyle increased throughout the study period, from 1985-2004 (Huntsinger et al. $2010 b)$.

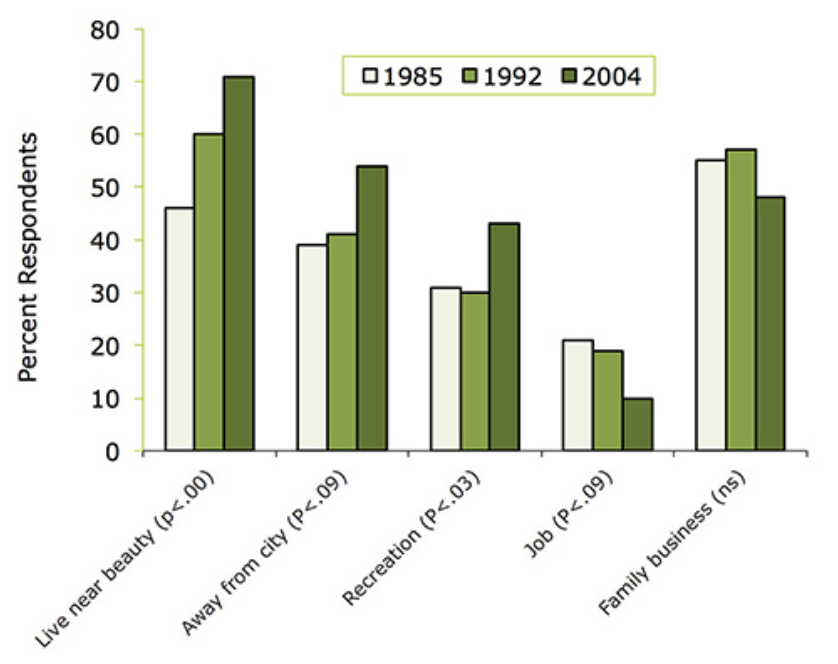

A contingent valuation study from Oviedo et al. (2012) verified the relationship between private amenity values and property size found in Huntsinger et al. (2010b), finding a statistically significant effect of property size on the per-ha valuation of nonmarket amenity values by landowners. The authors estimate a logarithmic model that indicates a nonlinear decrease in the perha valuation of nonmarket amenity values as property size increases. For example, for landowners with small properties $(<20$ ha) the marginal decline in the per-ha valuation of nonmarket amenity values is high $(\$ 18 / \mathrm{ha})$; for landowners with properties of 1000 ha or more, the marginal decline in the per-ha valuation of nonmarket amenity values is very small (\$0.05/ha). Results showed that landowner amenity values are present both on large and small properties, but they are relatively more important, on a per ha basis, for smaller properties. The research further revealed that amenity benefits or ecosystem service values saturate on a per ha basis as property size increases (Campos et al. 2009, Oviedo et al. 2012; Fig. 7). In contrast, returns from activities like livestock production continue to increase linearly with property size. Combining these two benefit streams is the basis for working landscapes and can be powerful motivation to keep ranchers in ranching. Ongoing research indicates that ranchers who are motivated by a combination of production and conservation goals are more active managers than other types of landowners (Ferranto et al. 2011).

Further support for the importance of understanding the joint production of commercial and amenity ecosystem services from social-ecological systems comes from an in-depth economic analysis of two ranches in California Mediterranean rangelands. Data from ranch commercial operations, land appreciation rates, and the nonmarket value of the private amenities consumed by ranchers as part of their annual income are integrated to compare rates of return (Oviedo et al. 2013; Table 2). As a result, the rates of return from the two ranch case studies differentiate between commercial and amenity returns as well as between returns deriving from operations and capital gains, the latter including land appreciation as its main component. The rate of return that ranchers received from ranchland investments was shown to derive mainly from the consumption of amenities, and from the land appreciation that, ultimately, is explained by future expectation of demand for these amenities (Table 2). The rate of return from range-based livestock production ("commercial" in Table 2) was low and even close to zero, illustrative of the decline in commercial returns from these enterprises.

Fig. 6. Amenity and lifestyle orientations, 1985-2004.

Notes: Amenity and lifestyle orientations have increased even in the largest property size categories, especially in the most recent period, as is shown by the influence of "having a different lifestyle" on landowner decisions to live in the oak woodlands in 1985, 1992, and 2004 (error bars are the 90\% confidence interval of the mean). There was no change in relative values by property size in 1985 and 1992, but in 2004, owners of properties larger than 80 ha were significantly more likely to report being influenced by the desire to have a different lifestyle than they were in 1985 ( $\mathrm{P}<0.02$ Chi-square). Very similar patterns and levels of significance were found for being "influenced by natural beauty" (adapted from Huntsinger et al. $2010 b$ )

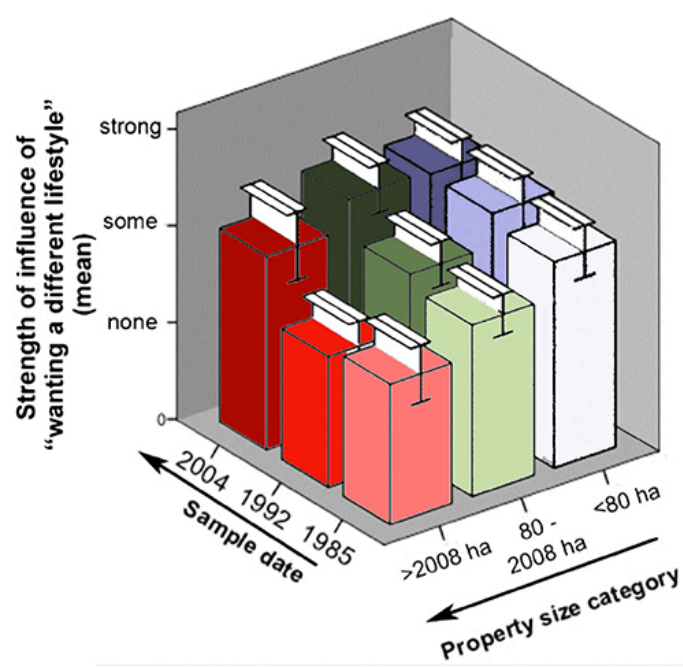


Table 2. Rates of return from commercial versus amenity income from two ranch case studies in California Mediterranean rangelands.

\begin{tabular}{|c|c|c|c|c|c|c|}
\hline \multirow[t]{2}{*}{ Rate of return indicators } & \multicolumn{3}{|c|}{ Ranch A } & \multicolumn{3}{|c|}{ Ranch B } \\
\hline & commercial & amenity & total & commercial & amenity & total \\
\hline$\%$ rate of return from operations $(\mathrm{O})$ & 2.0 & 2.4 & 4.5 & 0.1 & 3.8 & 4.0 \\
\hline$\%$ rate of return from capital gain $(\mathrm{C})$ & -0.7 & 8.2 & 7.5 & -0.2 & 7.3 & 7.0 \\
\hline Total rate of return $(\mathrm{O}+\mathrm{C})$ & 1.3 & 10.6 & 12.0 & -0.1 & 11.1 & 11.0 \\
\hline Total $\%$ rate of return in real terms & 1.1 & 8.2 & 9.3 & -0.1 & 8.4 & 8.3 \\
\hline
\end{tabular}

Notes: Land appreciation (included in the rate of return from capital gain) is estimated for the period 1999-2010 in order to show figures for an average year. Amenity income was calculated using a contingent valuation approach (adapted from Oviedo et al. 2013). Rate of return is estimated including subsidies net of taxes received by the rancher in the analyzed year. The rate of return in real terms is estimated discounting inflation, which averaged $2.7 \%$ in the period $1999-2010$.

In working woodland ecosystems, understanding that management decisions by landowners are affected by their consumption of ecosystems services is crucial to understanding investment decisions, and the rancher motivations and culture that influence the sustainability of the enterprise. At the same time, the flow of these ecosystem services is shaped according to rancher preferences.

Correlation analysis of oak woodland landowner data showed that one bundle of ecosystem goods and services supported by some landowners at the community level included livestock, timber, crops, and places to live, whereas another closely correlated bundle of biodiversity and ecosystem services included recreation, hunting/fishing, wildlife habitat, and fire prevention (Plieninger et al. 2012a). Producers were more likely to ally with the first bundle and residential owners with the second, but both groups were amenity and quality of life oriented. Producers were much more active in management for habitat improvement and other environmental goals than residential owners (Plieninger et al. 2012a). As the number of production-oriented owners decreases, developing strategies for encouraging environmentpositive management by all types of landowners is crucial. Research at this level includes enterprise economics, technology transfer, adoption studies, and social science-based projects. Outreach and advisory services have a major role at this scale.

It is important to note the interlinkage of the pasture and ranch scales: research at the pasture scale contributes to management improvements that can help support the ranch enterprise, resulting in a more sustainable ranch that persists in producing more ecosystem services at the ranch scale. Economically sustainable ranches, and landowners who are benefiting from their properties, have more resources and incentive to invest time and money in better ecosystem service management at the pasture scale. In turn, a commitment to permanence on the part of the rancher has important implications at the landscape scale (Huntsinger et al. 2010b).

\section{The landscape scale}

At the landscape scale, attention must be paid to the connectivity of habitat provided by ranches as a fundamental support for the ecosystem services produced by the social-ecological system of ranching. Ranching has been shown to be an important buffer between urban areas and public conservation lands (Talbert et al.
2007). For example, the rangelands surrounding California's prime croplands have been estimated to provide $>\$ 2$ billion in pollination services (Chaplin-Kramer et al. 2011).

Many ecosystem services, such as water production and filtering, habitat for large mammals, and aesthetic values, are produced at the landscape scale. It is increasingly necessary to coordinate management and interventions across property boundaries (Goldman et al. 2007, Plieninger et al. 2012b, Ferranto et al. 2013). This may require working with communities, local governance structures, and landowners, agencies, and land trusts that own or control access to rangelands. Ranching itself may extend across property boundaries through leasing to provide more and a yearround forage supply, sharing of pastures in time of drought, and seasonal mobility patterns (Huntsinger et al. 2010a). Tools and research topics at this scale include building Geographic Information Systems with substantial information about landuse change, vegetation, soils, topography, and political and social boundaries, developing approaches to collaborative management, and analyzing and researching public lands policy.

A decline in livestock production, revealed as ongoing in the oak woodland survey (Huntsinger et al. 2010b) and in range economics studies (Torell et al. 2005, Oviedo et al. 2013) could have important impacts on the ecosystem, and on the flow of ecosystem services, given the role of natural resource management at the ranch and pasture scale. Livestock grazing is critical in maintaining the structure and function of ranches, keeping grazing-related habitat characteristics, and supporting production of many of the current ecosystem services. The decline of commercial enterprises could encourage the abandonment of grazing. Because this will change ecosystem characteristics through the cessation of grazing, it will likely change the ecosystem services produced at the ranch and pasture levels, but ultimately also at the landscape level, especially given the uncertainty about whether or not a new generation of ranchers will hold the same amenity values and continue to fund them (Brunson and Huntsinger 2008). Across the western United States, multiple studies have shown that most ranching families subsidize their ranches with off-ranch income (Smith and Martin 1972, Gentner and Tanaka 2002, Huntsinger et al. 2010b). As discussed by Oviedo et al. (2012), the decline of commercial production could eventually lead to the subdivision of ranches, implying a potential threat from subsequent habitat and 
landscape fragmentation. Additionally, the high rates of land appreciation like those so prevalent in the early years of the $21^{\text {st }}$ century could enhance the trend of selling off small parcels so that ranchers can meet cash-flow shortages derived from low or negative commercial rate of returns (Oviedo et al. 2013).

Maintaining contiguous ranches benefits available habitat, and synergistically benefits the ranching community by providing a "critical mass" of ranches that can support ranching and marketing infrastructure and reduce conflicts with other land uses (Liffmann et al. 2000). A feedback loop has been posited in which the development of one ranch leads to the loss of the next ranch by incrementally changing environmental and social conditions, eventually shifting the landscape to a different land use (Huntsinger 2009; Fig. 8). Although some conservation organizations work to create landscapes of contiguous conservation areas by purchasing development rights or other strategies, public planning and zoning in the state remains piecemeal and relatively weak. Driven by urban outmigration and the second home market, oak woodlands have declined by thousands of ha/yr over the last decade, and are projected to continue to decline through 2040 (California Department of Forestry and Fire Protection-Fire and Resource Assessment Program 2003). One to 10-ha home sites, referred to as "ranchettes," are increasingly popular around the state; in Nevada county of the central Sierra foothills, the average parcel size shrank from 220 ha in 1957 to just 3.6 ha in 2001 (Meadows 2007).

Fig. 8.. Feedback loop accompanying rangeland conversion. Adapted from Huntsinger (2009).

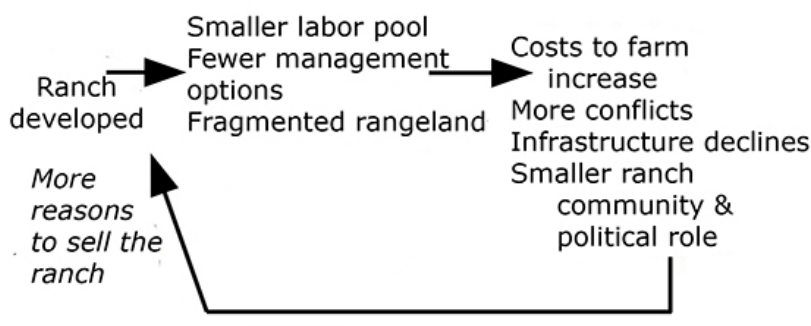

\section{Land use change feedback loop}

\section{The case of stock ponds}

Stock ponds provide a simple anecdotal example of the role of the three levels in producing ecosystem services. Like vernal pools, stock ponds constructed by ranchers in central coastal California have been shown to provide critical habitat for rare species, including the threatened California tiger salamander (Ambystoma californiense; United States Department of the Interior Fish and Wildlife Service 2004) and endangered red-legged frog (Rana aurora draytonii; United States Department of the Interior Fish and Wildlife Service 2006). At the pasture scale, the stockponds were created because ranchers needed them to water stock. Research has shown that the frogs and salamanders are more common in grazed ponds, and disappear or decline in fenced ponds (DiDonato 2007). Ranchers that find endangered species in their pond can qualify for a variety of government cost-share programs for otherwise very costly pond maintenance and repair. When they take part in such programs, it is sometimes hard to convince agencies, conservation NGOs, and environmental consultants that fencing is a bad idea, because of the assumption that commodity production is bad for wildlife habitat (Huntsinger et al. 2012).

At the ranch level, ranchers benefit from the reduced costs from cost sharing, and from legislation excusing them if some of the salamanders and frogs are harmed by normal ranch operations (United States Department of the Interior Fish and Wildlife Service 2004, 2006). Otherwise, it would be impossible to continue to use the pond. Ranchers have reported that they like to feel that they are doing something that is widely appreciated by the public in protecting the wildlife, and this may increase their personal sense of satisfaction (Huntsinger et al. 2012). At the landscape scale, ranchers can qualify for mitigation easements to preserve habitat for endangered and rare species, meaning the development rights to the habitat are alienated from the property and sold. This provides income at the ranch scale, and long-term conservation at the landscape scale, avoiding or reducing the threat of fragmentation. The value of the habitat will be greatly influenced by adjacent land uses at the landscape scale and, in fact, the salamanders migrate about $1.5 \mathrm{~km}$ to nearby ponds-about the distance typically separating one water source from another on a cattle ranch. The county's "urban limit line," part of the local land-use plan, may help. In sum, the pond in the pasture would not exist without the ranch, and the ranch will disappear without the landscape. Conserving the pond species and habitat conditions suitable for them requires tools appropriate to pasture-, ranch-, and landscape-level social-ecological processes.

\section{CONCLUSIONS}

A common mistake in the analysis of human-shaped ecosystems such as California's working woodlands is assuming that the flow of seemingly "natural" ecosystem services will persist and even be enhanced with the cessation of human use of the ecosystem. However, the complexity of the feedbacks and interdependencies in a social-ecological system are not understood. California's Mediterranean rangelands, although used and managed for thousands of years, appear very natural. However, in a socialecological system like ranching that pervades Mediterranean rangelands, the production of many ecosystem services is dependent on the participation of livestock, ranchers, and ranching communities, as has been described here. To conserve many ecosystem services then, the entire social-ecological system must be tended to at multiple scales. For example, Habitat Conservation Plans carried out to satisfy the Endangered Species Act are designed to protect wildlife in a country or region. In Mediterranean rangeland areas, species descriptions required by the process generally mention that several of the endangered species described in the plan are observed to do better with livestock grazing. However, where the livestock will come from in the long term is not considered, nor is the interaction of pasture, ranch, and landscape scales in the provision of habitat conditions through grazing. Instead, the draft recommendation is often that large areas of land be acquired and managed by the government to conserve wildlife, but no similar thought is given to the resources needed to maintain the ranching community over time. The ability of ranches to prosper, and the need for access to enough pastures for year-round operation, is not considered. Even when they are convinced that livestock grazing is essential 
for maintaining species abundance, managers and planners often fail to consider the ranches or people that produce stock. As in many parts of the world, government and nongovernmental organizations frequently hire "professional land managers" or "environmental consultants" who do not know the rancher's perspective, or understand the imperatives of the pastoralist operation. Another manifestation of this lack of understanding is the development of highly complex grazing plans for public lands habitat goals - for example, asking a lessee to move 200 cattle onto an area for two weeks at a specified time-an action that cannot be carried out affordably by the rancher. This trend may eventually mean that instead of paying to graze some areas, a rancher might be paid as part of a PES scheme.

At the pasture scale, tools that encourage the production of social-ecological services without raising costs that threaten sustainability at the ranch scale are needed. These include PES and other incentives for particular practices, technical advising, and education. At the ranch scale, increasing the sustainability of ranching enterprises, including facilitating the development of a new generation of ranchers, is important, and leveraging the power of rancher motivations stemming from their own ecosystem-service consumption is crucial. Market-based approaches that increase and diversify income, PES opportunities, and tax-relief programs for agricultural land uses, have particular resonance at this scale. At the landscape scale, considering the need for critical mass, cross-boundary cooperation, maintaining ranching community infrastructure, the synergies of clusters, and the patterns of urban outgrowth are important. Conservation easements, zoning, community organizations and outreach, and coordination across property boundaries are different factors that are required to slow or counter a feedback loop which accelerates development and the loss of ecosystem services.

Intensification of agriculture presents challenges at each scale. Traditional pastoralism and traditional California ranching rely on largely working with natural processes and using natural resources in a continual process of learning and adaptation to an unpredictable climate and resource base. Shifting to a greater reliance on energy and chemical inputs, and grain and hay crops, leads to a broader decoupling from ecosystem processes. At the pasture scale, intensification typically leads to the breaking up of large grazing areas into smaller units, fragmenting habitat and degrading aesthetic resources. Outcomes of intensive management may include environmental "bads" such as habitat loss, nutrient runoff, or pesticide poisoning of nontarget species (Zhang et al. 2007). Ranches may consolidate and shift from a focus on learning and adaptation, and diversification of income streams, to adoption of new technologies for manipulating the environment, increasing livestock numbers, and reducing dependence on sustaining the health of arid rangelands that cannot produce more than the weather allows. At the landscape scale, intensification can lead to large-scale simplification (Geri et al. 2010, Plieninger 2011), as homogenization and streamlining of production creates a uniform model for land management. The entire system becomes increasingly reliant on cultivation and its energy, chemical, and water inputs.

Ecosystem services at the landscape level are enjoyed by ranchers. For example, "living near natural beauty" was given as an important reason to engage in ranching by a large majority of ranchers in the oak woodland survey, as was "living away from the city" (Huntsinger et al. 2010b). The general public is also a major consumer of these kinds of services, enjoying viewsheds and open space. The fact that many of these ecosystem services are not marketable makes it difficult to assess the impact of the interactions across the three levels at which they are provided. This remains as one the main challenges faced by scientists interested in the analysis of social-ecological ecosystems. Nonmarket valuation has been applied for decades but efforts to integrate in scientific and economic analysis market and nonmarket values are recent (Caparrós et al. 2003, Campos and Caparrós 2009).

One example of using a multiscaled conservation approach is that of the California Rangeland Conservation Coalition (Alvarez 2011). A grassroots organization formed from a coalition of ranchers, environmentalists, and agencies, the coalition approaches rangeland conservation at all three scales. At the pasture scale, the group promotes good grazing management, and educates members about opportunities to obtain cost-share funding to support practices that contribute to ranch productivity, as well as increased ecosystem services. At the ranch level, the group offers a sense of camaraderie, social support, information about marketing opportunities, and supports ways to increase productivity and profits. It promotes ecosystem services as a potential source of income through identifying and informing about the services produced through rancher stewardship. The participation of agency personnel helps ranchers find opportunities to reduce costs and increase income, and helps ranchers communicate their constraints, as well as stewardship activities, to agencies.

At the landscape level, the group works with the California Rangeland Trust, an NGO that helps ranchers put conservation easements on their land. In addition, the Coalition sponsored the "California Rangeland Resolution," a document signed by $>100$ natural resource agencies, agricultural organizations, and conservation groups stating that the diversity of species rangelands support is largely attributed to grazing and other land stewardship practices of the ranchers that own and manage them. One concern that keeps some ranchers from participating is a sense that they can't believe the conservation community cares about their profitability (K. Sweet, personal communication). In other words, they don't believe that the drivers and processes that keep the ranch-level system going are understood and considered by nonranchers.

In sum, social ecosystem services from the pasture depend on maintaining the ranch and the landscape. In turn, landscape-level services cannot be maintained without the pasture and the ranch. Attention to all three scales, and synergies between conservation and production, supports the sustainability of the working landscape and its social-ecological services.

Responses to this article can be read online at: http://www.ecologyandsociety.org/issues/responses. $\mathrm{php} / 6143$ 


\section{Acknowledgments:}

The authors acknowledge the funding received from the projects "Assessing the non-market values of California ranches (CIG05-178)" of the Division of Agriculture and Natural Resources of the University of California and "The bioeconomics of Mediterranean oak woodlands in Spain and California (ILink0253)" of the Spanish National Research Council (CSIC), and from the U.S. Agricultural Experiment Station. We would also like to thank the two anonymous reviewers for their constructive and insightful reviews.

\section{LITERATURE CITED}

Allen, T. F. H., and T. B. Starr. 1982. Hierarchy: perspectives for ecological complexity. University of Chicago Press, Chicago, USA.

Allen-Diaz, B., J. Bartolome, and M. P. McClaran. 1999. California oak savanna. Pages 322-329 in R. C. Anderson, J. S. Fralish, and J. M. Baskin, editors. Savannas, barrens, and rock outcrop plant communities of North America. Cambridge University Press, Cambridge, UK.

Allen-Diaz, B., R. Standiford, and R. D. Jackson. 2007. Oak woodlands and forests. Pages 313-338 inM. G. Barbour, T. KeelerWolf, and A. A. Schoenherr, editors. Terrestrial vegetation of California. University of California Press, Berkeley, California, USA.

Alvarez, P. 2011. Conserving and managing prairie, grassland, and vernal pool landscapes through collaboration. Fremontia 39 (2-3):49-54. [online] URL: http://www.cnps.org/cnps/publications/ fremontia/FremontiaV39.2 39.3.pdf

Anderson, K. M. 2005. Tending the wild: Native American knowledge and the management of California's natural resources. University of California Press, Berkeley, California, USA.

Barry, S. J. 2011. Current findings on grazing impacts of California's special status species. Santa Clara Cooperative extension newsletter keeping landscapes working 7:2-6. [online] URL: http://cesantaclara.ucdavis.edu/news 719/

Keeping_Landscapes_Working/?newsitem $=33238$

Birks, H. H., H. J. B. Birks, P. E. Kaland, and D. Moe, editors. 1988. The cultural landscape: past, present, and future. Cambridge University Press, Cambridge, UK.

Blackburn, T. C., and K. Anderson, editors. 1993. Before the wilderness: environmental management by native Californians. Ballena, Menlo Park, California, USA.

Booker, K., L. Huntsinger, J. W. Bartolome, N. Sayre, and W. Stewart. 2012. What can ecological science tell us about opportunities for carbon sequestration on arid rangelands in the United States? Journal of Global Environmental Change 23 (1):240-251. http://dx.doi.org/10.1016/j.gloenvcha.2012.10.001

Brunson, M., and L. Huntsinger. 2008. Can old ranchers save the new west? Rangeland Ecology and Management 61(2):137-147. [online] URL: http://dx.doi.org/10.2111/07-063.1

Bugalho, M. N., M. C. Caldeira, J. S. Pereira, J. Aronson, and J. G. Pausas. 2011. Mediterranean cork oak savannas require human use to sustain biodiversity and ecosystem services. Frontiers in Ecology and the Environment 9(5):278-286. http://dx. doi.org/10.1890/100084

Burcham, L. T. 1982. California range land: an historicoecological study of the range resource of California. Center for Archeological Research at Davis, Publication Number 7. University of California Press, Davis, California, USA.

California Department of Forestry and Fire Protection-Fire and Resource Assessment Program (CDF-FRAP). 2003. The changing California: forest and range 2003 assessment. State of California Resources Agency, Sacramento, California, USA. [online] URL: http://frap.fire.ca.gov/data/assessment2003/

California Department of Forestry and Fire Protection-Fire and Resource Assessment Program (CDF-FRAP). 2006. 2006. Land cover: multi-source data compiled in 2006. State of California Resources Agency, Sacramento, California, USA. [online] URL: http://frap.fire.ca.gov/data/frapgismaps/pdfs/fvegwhr13b map.pdf

California Department of Forestry and Fire Protection-Fire and Resource Assessment Program (CDF-FRAP). 2010. California's forests and rangeland: the 2010 assessment. State of California Resources Agency, Sacramento, California, USA. [online] URL: http://frap.fire.ca.gov/assessment/2010/details.php

Campos, P., and A. Caparrós. 2009. Can we use non-market valuation techniques in green national accounting applied to forests? Austrian Journal of Forest Science 126:53-76. [online] URL:http://digital.csic.es/handle/10261/23541

Campos, P., J. L. Oviedo, A. Caparros, L. Huntsinger, and I. Coelho. 2009. Contingent valuation of woodland-owners private amenities in Spain, Portugal, and California. Rangeland Ecology and Management 62(3):240-252. http://dx.doi.org/10.2111/08-178R2.1

Caparrós, A., P. Campos, and G. Montero. 2003. An operative framework for total Hicksian income measurement: application to a multiple-use forest. Environmental and Resource Economics 26(2):173-198. http://dx.doi.org/10.1023/A:1026306832349

Chaplin-Kramer, R., K. Tuxen-Bettman, and C. Kremen. 2011. Value of wildland habitat for supplying pollination services to Californian agriculture. Rangelands 33(3):33-41. http://dx.doi. org/10.2111/1551-501X-33.3.33

Cheatum, M., F. Casey, P. Alvarez, and B. Parkhurst. Payments for ecosystem services: a California rancher perspective. Conservation economics and finance white paper. Defenders of Wildlife, Washington, D.C., USA. [online] URL: http://www. carangeland.org/images/payments_for_ecosystem_services_a_california rancher perspective.pdf

Cuff, D. 2011. Cow's hoofs and healthy appetite help bring back endangered Contra Costa goldfields. Contra Costa Times 2 June 2011, Walnut Creek, California, USA. [online] URL: http://www. mercurynews.com/breaking-news/ci 18178771?nclick check=1

de Snoo, G. R., I. Herzon, H. Staats, R. J. F. Burton, S. Schindler, J. van Dijk, A. M. Lokhorst, J. M. Bullock, M. Lobley, T. Wrbka, G. Schwarz, and C. J. M. Musters. 2012. Towards effective nature conservation on farmland: making farmers matter. Conservation Letters 6(1):66-72. http://dx.doi.org/10.1111/j.1755-263X.2012.00296. $\underline{x}$ 
Dennis, P., M. R. Young, C. L. Howard, and I. J. Gordon. 1997. The response of epigeal beetles (Col. Carabidae, Staphylinidae) to varied grazing regimes on upland Nardus stricta grasslands. Journal of Applied Ecology 34(2):433-443. [online] URL: http:// www.jstor.org/stable/2404888

DiDonato, J. 2007. Endangered amphibian research within grazed grasslands. Keeping landscapes working. University of California Cooperative Extension Newsletter for Rangeland Managers. Winter 2007:4-6. [online] URL: http://cesantaclara. ucanr.edu/newsletters/Winter 200725463.pdf

Ferranto, S., L. Huntsinger, C. Getz, M. Lahiff, W. Stewart, G. Nakamura, and M. Kelly. 2013. Management without borders? A survey of landowner practices and attitudes towards crossboundary cooperation. Society and Natural Resources 26 (9):1082-1100 http://dx.doi.org/10.1080/08941920.2013.779343

Ferranto, S., L. Huntsinger, C. Getz, G. Nakamura, W. Stewart, S. Drill, Y. Valachovic, M. DeLasaux, and M. Kelly. 2011. Forest and rangeland owners value land for natural amenities and as financial investment. California Agriculture 65(4):185-191. http:// dx.doi.org/10.3733/ca.v065n04p184

Foster, D., F. Swanson, J. Aber, I. Burke, N. Brokaw, D. Tilman, and A. Knapp. 2003. The importance of land-use legacies to ecology and conservation. BioScience 53(1):77-88. http://dx.doi. org/10.1641/0006-3568(2003)053[0077:TIOLUL]2.0.CO;2

Fox, J. 1992. The problem of scale in community resource management. Environmental Management 16(3):289-297. http:// dx.doi.org/10.1007/BF02400067

Frost, W.E., J. W. Bartolome, and J. M. Connor. 1997. Understory-canopy relationships in oak woodlands and savannas. General Technical Report PSW-GTR-160. Pages 183190 in N. H. Pillsbury, J. Verner, and W. D. Tietje, technical coordinators. Proceedings of a symposium on oak woodlands: ecology, management and urban interface issues 19-24 March 1996, San Luis Opisbo, California, USA. Pacific Southwest Research Station, Forest Service, U.S. Department of Agriculture (USDA), Albany, Califonria, USA. [online] URL: http://www.fs. fed.us/psw/publications/documents/psw_gtr160/psw_gtr160_04_frost. pdf

Frost, W. E., and N. K. McDougald. 1989. Tree canopy effect on herbaceous production of annual rangeland during drought. Journal of Range Management 42(4):281-283. [online] URL: http://www.jstor.org/stable/3899494

Frost, W. E., N. K. McDougald, and M. W. Demment. 1991. Blue oak canopy effect on seasonal forage production and quality. General Technical Report PSW-126. Pages 307-311 in R. B. Standiford, technical coordinator. Proceedings of a symposium on oak woodlands and hardwood rangeland management 31 October - 2 November 1991, Davis, California, USA. Pacific Southwest Research Station, Forest Service, U.S. Department of Agriculture (USDA), Albany, Califonria, USA. [online] URL: http://www.fs. fed.us/psw/publications/documents/psw gtr126/psw gtr126 05 frost. pdf

Gentner, B., and J. A. Tanaka. 2002. Classifying federal public land grazing permittees. Journal of Range Management 55(1):211. [online] URL: http://www.jstor.org/stable/4003256
Germano, D. J., G. B. Rathbun, and L. R. Saslaw. 2011. Effects of grazing and invasive grasses on desert vertebrates in California. Journal of Wildlife Management 76(4):670-682. http://dx.doi. org/10.1002/jwmg.316

Geri, F., V. Amici, and D. Rocchini. 2010. Human activity impact on the heterogeneity of Mediterranean landscape. Applied Geography 30(3):370-379. http://dx.doi.org/10.1016/j.apgeog.2009.10.006

Goldman, R. L., B. H. Thompson, and G. C. Daily. 2007. Institutional incentives for managing the landscape: Inducing cooperation for the production of ecosystem services. Ecological Economics 64(2):333-343. http://dx.doi.org/10.1016/j.

ecolecon.2007.01.012

Gunderson, L. H., and C. S. Holling. 2002. Panarchy: understanding transformations in human and natural systems. Island Press, Washington, D.C., USA.

Heimlich, R. E., and W. D. Anderson. 1987. Dynamics of land use change in urbanizing areas: experience in the economic research service. Pages 135-154 in W. Lockeretz, editor. Sustaining agriculture near cities. Soil and Water Conservation Service, Washington, D.C., USA.

Holling, C. S. 2001. Understanding the complexity of economic, ecological, and social systems. Ecosystems 4(5):390-405. http:// dx.doi.org/10.1007/s10021-001-0101-5

Holstein, G. 2011. Prairies and grasslands: what's in a name? Fremontia 39(2-3):2-5. http://www.cnps.org/cnps/publications/ fremontia/FremontiaV39.2 39.3.pdf

Huntsinger, L. 2009. Into the wild: vegetation, alien plants, and familiar fire at the exurban frontier. Pages 133-156 in A. Esparza, and G. McPherson, editors. The planner's guide to natural resource conservation: the science of land development beyond the metropolitan fringe. Springer, New York, New York, USA.

Huntsinger, L., J. W. Bartolome, and C. M. D'Antonio. 2007. Grazing management of California grasslands. Pages 233-253 in J. Corbin, M. Stromberg, and C. M. D’Antonio, editors. Ecology andmanagement of California grasslands. University of California Press, Berkeley, California, USA.

Huntsinger, L., L. Buttolph, and P. Hopkinson. 1997. Ownership and management changes on California hardwood rangelands: 1985 to 1992. Journal of Range Management 50(4):423-430. [online] URL: http://www.jstor.org/stable/4003311

Huntsinger, L., and L. P. Fortmann. 1990. California privately owned oak woodlands - owners, use, and management. Journal of Range Management 43(2):147-152. [online] URL: http://www. jstor.org/stable/3899034

Huntsinger, L., L. C. Forero, and A. Sulak. 2010a. Transhumance and pastoralist resilience in the western United States. Pastoralism: research, policy, and practice 1(1):1-15. [online] URL: http://pubs.iied.org/X00038.html

Huntsinger, L., M. Johnson, M. Stafford, and J. Fried. $2010 b$. Hardwood rangeland landowners in California from 1985 to 2004: production, ecosystem services, and permanence. Rangeland Ecology and Management 63(3):325-334. http://dx. doi.org/10.2111/08-166.1 
Huntsinger, L., and N. Sayre. 2007. Introduction: the working landscapes special issue. Rangelands 23(3):9-13. [online] URL: http://www.jstor.org/stable/4640268

Huntsinger, L., N. Sayre, and J. D. Wulfhorst. 2012. Birds, beasts and bovines: three cases of U.S. pastoralism and wildlife. Pastoralism: research, policy, and practice 2(12). http://dx.doi. org/10.1186/2041-7136-2-12

Kelt, D. A., E. S. Konno, and J. A. Wilson. 2005. Research notes: habitat management for the endangered Stephens' kangaroo rat: the effect of mowing and grazing. Journal of Wildlife Management 69(1):424 429. http://dx.doi.org/10.2193/0022-541X(2005)069<0424: HMFTES $>2.0 . \mathrm{CO} ; 2$

Liffmann, R. H., L. Huntsinger, and L. C. Forero. 2000. To ranch or not to ranch: home on the urban range? Journal of Range Management 53(4):362-370. [online] URL: http://www.jstor.org/ stable/4003745

Marty, J. T. 2005. Effects of cattle grazing on diversity in ephemeral wetlands. Conservation Biology 19(5):1626-1632. http://dx.doi.org/10.1111/j.1523-1739.2005.00198.x

McAllister, R. R. J., N. Abel, C. J. Stokes, and I. J. Gordon. 2006. Australian pastoralists in time and space: the evolution of a complex adaptive system. Ecology and Society 11(2):41. [online] URL: http://www.ecologyandsociety.org/vol11/iss2/art41/

McClaran, M. P., and J. W. Bartolome. 1985. The importance of oaks to ranchers in the California foothill woodland. Rangelands 7(4):158-161. [online] URL: http://www.jstor.org/stable/3900746

McCreary, D. 2001. Regenerating rangeland oaks in California. Department of Agriculture and Natural Resources, University of California Extension Service, Davis, California, USA. [online] URL: http://ucanr.edu/sites/oak range/files/59453.pdf

McGarrahan, E. 1997. Much-studied butterfly winks out on Stanford preserve. Science 275(5299):479-480. http://dx.doi. org/10.1126/science.275.5299.479

Meadows, R. 2007. Oaks: research and outreach to prevent woodland loss. California Agriculture 61(1):7-10. [online] URL: http://californiaagriculture.ucanr.org/landingpage.cfm?articleid= ca.v061n01p7

Millennium Ecosystem Assessment (MEA). 2003. Ecosystems and human well-being: a framework for assessment. Island Press, Washington, D.C., USA.

Myers, N., R. A. Mittermeier, C. G. Mittermeier, G. A. B. da Fonseca, and J. Kent. 2000. Biodiversity hotspots for conservation priorities. Nature 403:853-858. http://dx.doi.org/10.1038/35002501

Norgaard, R. B. 2010. Ecosystem services: from eye-opening metaphor to complexity blinder. Ecological Economics 69 (6):1219-1227. http://dx.doi.org/10.1016/j.ecolecon.2009.11.009

Nuzum, R. C. 2005. Report: using livestock grazing as a resource management tool in California. Contra Costa Water District report, Concord, California, USA. [online] URL: www.ccwater. com/files/LivestockGrazingFinal72005.pdf

Oviedo, J. L., L. Huntsinger, P. Campos, and A. Caparrós. 2012. Income value of private amenities in California oak woodlands.
California Agriculture 66(3):91-96. http://dx.doi.org/10.3733/ca. v066n03p91

Oviedo J. L., P. Ovando, L. C. Forero, L. Huntsinger, A. Alvarez, B. Mesa and P. Campos. 2013. The private economy of dehesa and ranches: case studies. Pages 389-426 in P. Campos, L. Huntsinger, J. L. Oviedo, P. F. Starrs, M. Díaz, R. Standiford, and G. Montero, editors. Mediterranean oak woodland working landscapes: Dehesas of Spain and ranchlands of California. Springer, Berlin, Germany. http://dx.doi.org/10.1007/978-94-007-6707-2 13

Plieninger, T. 2011. Monitoring directions and rates of change in trees outside forests through multitemporal analysis of map sequences. Applied Geography 32(2):566-576. http://dx.doi. org/10.1016/j.apgeog.2011.06.015

Plieninger, T., S. Ferranto, L. Huntsinger, C. Getz, and M. Kelly. 2012a. Appreciation, use, and management of biodiversity and ecosystem services in California's working landscapes. Environmental Management 50(3):427-440. http://dx.doi.org/10.1007/ $\underline{\mathrm{s} 00267-012-9900-\mathrm{Z}}$

Plieninger, T., C. Schleyer, H. Schaich, B. Ohnesorge, H. Gerdes, M. Hernandez-Morcillo, and C. Bieling. 2012b. Mainstreaming ecosystem services through reformed European agricultural policies. Conservation Letters 5(4):281-288. http://dx.doi. org/10.1111/j.1755-263X.2012.00240.X

Pyke, C. R., and J. Marty. 2005. Cattle grazing mediates climate change impacts on ephemeral wetlands. Conservation Biology 19 (5):1619-1625. http://dx.doi.org/10.1111/j.1523-1739.2005.00233. $\underline{x}$

Reiner, R. 1999. Protecting biodiversity on grazed grasslands in California. American Association for the Advancement of Science, 24 January 1999, Anaheim, California, USA. [online] URL: http://californiarangeland.ucdavis.edu/Publications $\% 20$ pdf/ CRCC/Protecting $\% 20$ Biodiversity $\% 20$ on $\% 20$ Grazed $\% 20$ Grasslands $\%$ 20in\%20California.pdf

Reiner, R., and A. Craig. 2011. Conservation easements in California blue oak woodlands: assumption of livestock grazing as a compatible use. Natural Areas Journal 31(4):408-413. http:// dx.doi.org/10.3375/043.031.0411

Sayre, N. F., L. Carlisle, L. Huntsinger, G. Fisher, and A. Shattuck. 2012. The role of rangelands in diversified farming systems: innovations, obstacles, and opportunities. Ecology and Society 17 (4): 43. http://dx.doi.org/10.5751/ES-04790-170443

Schleyer, C., and T. Plieninger. 2011. Obstacles and options for the design and implementation of payment schemes for ecosystem services provided through farm trees in Saxony, Germany. Environmental Conservation 38(4):454 463. http://dx.doi.org/10.1017/ $\underline{\mathrm{S} 0376892911000361}$

Seastedt, T. R., R. J. Hobbs, and K. N. Suding. 2008. Management of novel ecosystems: are novel approaches required? Frontiers in Ecology and the Environment 6(10):547-553. [online] URL: $\underline{\text { http:// }}$ dx.doi.org/10.1890/070046

Smith, A. H., and W. E. Martin. 1972. Socioeconomic behavior of cattle ranchers with implications for rural community 
development in the West. American Journal of Agricultural Economics 54(2):217-225. http://dx.doi.org/10.2307/1238704

Standiford, R. B., and R. E. Howitt. 1992. Solving empirical bioeconomic models: a rangeland management application. American Journal of Agricultural Economics 74(2):421-433. http://dx.doi.org/10.2307/1242496

Stanford University Multidisciplinary Teaching and Research. 2013. Field research at Jasper Ridge. Stanford University, Palo Alto, California, USA. [online] URL: http://news.stanford.edu/ news/multi/features/jasper/part2.html

Talbert, C. B., R. L. Knight, and J. E. Mitchell. 2007. Private ranchlands and public land grazing in the southern Rocky Mountains. Rangelands 29(3):5-8. [online] URL: http://www. jstor.org/stable/4640269

Torell, L. A., N. R. Rimbey, O. A. Ramirez, and D. W. McCollum. 2005. Income earning potential versus consumptive amenities in determining ranchland values. Journal of Agricultural and Resource Economics 30(3):537-560. [online] URL: http://purl. umn.edu/30986

United States Department of the Interior Fish and Wildlife Service (USDI-FWS). 1997. Draft recovery plan for the Stephen's kangaroo rat, Region 1. USDI-FWS, Portland, Oregon, USA. [online] URL: http://ecos.fws.gov/docs/recovery plan/970623. pdf

United States Department of the Interior Fish and Wildlife Service (USDI-FWS). 2004. Determination of threatened status for the California tiger salamander; and special rule exemption for existing routine ranching activities; final rule. USDI-FWS, Washington, D.C., USA, Federal Register 71:47211-47248 [online] URL: http://www.fws. gov/policy/library/2004/04-17236. $\underline{\mathrm{html}}$

United States Department of the Interior Fish and Wildlife Service (USDI-FWS). 2006. Designation of critical habitat for the California red-legged frog, and special rule exemption associated with final listing for existing routine ranching activities: final rule. Federal Register 71:19243-19346. USDI-FWS, Washington, D. C., USA. [online] URL: http://www.fws.gov/policy/library/2006/06-3344. $\underline{\mathrm{html}}$

United States Department of the Interior Fish and Wildlife Service (USDI-FWS). 2010. San Joaquin kit fox (Vulpes macrotis mutica), 5-year review: summary and evaluation. U.S. Fish and Wildlife Service, Sacramento, California, USA. [online] URL: http://ecos.fws.gov/docs/five year review/doc3222.pdf

Weiss, S. B. 1999. Cars, cows, and checkerspot butterflies: nitrogen deposition and management of nutrient-poor grasslands for a threatened species. Conservation Biology 13(6):1476-1486. http:// dx.doi.org/10.1046/j.1523-1739.1999.98468.X

Zhang, W., T. H. Ricketts, C. Kremen, K. Carney, and S. M. Swinton. 2007. Ecosystem services and dis-services to agriculture. Ecological Economics 64(2):253-260. https://www.msu.edu/ swintons/Reprints/ZhangEtAl-EcosysSvcs+DisservicesToAgricEcolEcon2007printed.pdf 